\title{
Antidiabetic Effect of Ipomoea Batatas in Normal and Alloxan- Induced Diabetic Rats
}

\author{
Ijaola T.O ${ }^{1}$, Osunkiyesi A. A ${ }^{1}$, Taiwo A.A ${ }^{1}$, Oseni O.A ${ }^{1}$, LanreIyanda \\ Y.A. ${ }^{1}$,Ajayi J.O ${ }^{2}$ andOyede R.T. ${ }^{3}$ \\ ${ }^{I}$ Chemistry unit, Department of Science Laboratory Technology, Moshood Abiola Polytechnic Abeokuta Ogun \\ State Nigeria \\ ${ }^{2}$ Biology/Microbiology unit, Department of Science Laboratory Technology, Moshood Abiola Polytechnic \\ Abeokuta Ogun State Nigeria \\ ${ }^{3}$ Chemistry unit, Department of Science Laboratory Technology, Federal Polytechnic Ilaro Ogun State Nigeria
}

\begin{abstract}
The hypoglycemic effects of graded quantities $(200 \mathrm{mg} / \mathrm{kg}, 300 \mathrm{mg} / \mathrm{kg}$ and $400 \mathrm{mg} / \mathrm{kg} / \mathrm{day}$ ) of Ipomeabatatas leaf extracts at a dose of once daily for fourteen days on the blood glucose level of 20 rats whose glucose level exceeded 200mg/dl after alloxan induction were studied. Qualitative and quantitative analysis of phytochemical ingredients of Ipomeabatatas leaf were also carried out. Data obtained were subjected to Analysis of variance (ANOVA) with probability set at $p<0.05$. The results showedthat oral treatment with $2 \mathrm{ml}$ of $200 \mathrm{mg} / \mathrm{kg} /$ day of Ipomoea batatas aqueous extract did not produce significant $(p>0.05)$ alterations in the blood glucose concentration level when compared with basal value. Also, there was no significant difference ( $p>0.05)$ in the sugar level of rats treated with $300 \mathrm{mg} / \mathrm{kg} /$ day and $400 \mathrm{mg} / \mathrm{kg} /$ day of the extracts but the hypoglycemic effect significantly differ $(p<0.05)$ from non-diabetic and rats treated with oral administration of $200 \mathrm{mg} / \mathrm{kg} / \mathrm{day}$ of Ipomeabatata extracts. Thehighest percentage blood sugar reductions of $69.67 \%$ was recorded in rats treated with $300 \mathrm{mg} / \mathrm{kg} / \mathrm{day}$, followed by $59.24 \%$ ( 400 $\mathrm{mg} / \mathrm{kg} /$ day extract) while the least percentage sugar reduction of $52.18 \%$ was observed in $200 \mathrm{mg} / \mathrm{kg} /$ day extract. The non-diabetic induced rats exhibited steady increase $(8.03 \%)$ in their normal glucose level. It was revealed that alloxan induced rats treated with $200 \mathrm{mg} / \mathrm{kg} / \mathrm{day}$, $300 \mathrm{mg} / \mathrm{kg} /$ day and $400 \mathrm{mg} / \mathrm{kg} /$ day sustained percentage weight loss of $48.91,28.66$ and 31.11 percent respectively compared with non-diabetic induced rats. The qualitative phytochemical screening investigation of Ipomeabatata indicated the presence of alkaloids, flavonoids, tannins, saponins, steroids, phenol, anthraquinone, Phlobatannin, Glycosides and terpenoids. Also, quantitative phytochemical study revealed that saponin (6.21) was the highest phytochemical content followed by tannin (4.15) while Glycoside was the least (0.40).In conclusion, 300mg/kg/day of the extract produced the best hypoglycemic effect (69.67\%) in diabetic induced rats.
\end{abstract}

Keywords: Alloxan-induced rats,Anti-diabetes, Diabetes, Ipomoea batatas, phytochemical analysis.

\section{Introduction}

Diabetes mellitus (diabetes) is a group of metabolic diseases in which a person has high blood sugar, either because the body does not produce enough insulin, or because cells do not respond to the insulin that is produced $^{(1)}$. High blood sugar or hyperglycemia is a condition in which an excessive amount of glucose circulates in the blood plasma. It was first identified as a disease associated with excessive muscle loss in the ancient world and sweet urine which resulted from slippage of glucose into the urine ${ }^{(2)}$.

It can be classified into four broad categories: namely type 1, type 2, gestational and "other specific type" diabetes. The other specific type are a collection of a few dozen individual causes ${ }^{(1)}$. The term "type 1" diabetes has replaced several former terms, including childhood onset diabetes and the term "type 2" has replaced several formal types including adult onset, obesity related diabetes and NIDDM (Non-insulin dependent diabetes mellitus). Beyond these two types there is no agreed standard nomenclature ${ }^{(3)}$.Its causes vary depending on genetics make up, family history, health and environmental factors. Type 1 diabetes is partly inherited and is caused by the immune system destroying the cells in the pancreas that makes the insulin and then triggered by certain infections, with some evidence pointing at caxasackie before virus. However, even in those who have inherited the susceptibility, type 1 diabetes seems to require an environmental trigger in which the onset of type 1 diabetes is unrelated to life style ${ }^{(4)}$.

Type 2 diabetes causes are usually multifactorial, because more than one diabetes cause is involved. It is primarily due to lifestyle factors, obesity, living a sedentary lifestyle, bad diet and genetics ${ }^{(4)}$. The causes of gestational diabetes remain unknown. However, there are a number of risk factors such as family history, overweight or obese, having a large baby weighing over 9 pounds etc., these increase the chances of developing this condition ${ }^{(4)}$. 
People with type 1 diabetes who are not being treated early enough urinate frequently and feel excessively thirsty. They usually feel very tired and experience severe weight loss despite normal or excessive food intake. The symptoms of type 2 diabetes usually appear more gradually. People with type 2 diabetes who do not have their blood glucose under control often have a persistent, mild thirst. Many women with this disease have recurring vaginal yeast infections ${ }^{(4)}$.

The disease is a major endocrine disorder affecting nearly $10 \%$ of the world's population and it is reported to be rapidly increasing particularly in the developing countries due to population growth, urbanization, increasing prevalence of obesity and sedentary lifestyle, in addition to genetic predisposition ${ }^{(5)}$. It is a major cause of heart disease, one of the leading causes of death in the world. It is also the biggest cause of blindness and kidney failure in adults. Older adults with diabetes are twice as likely to develop high blood pressure as people without diabetes. People with diabetes are also much likely to undergo foot and other "lower extremity" amputations due to circulatory problems. Between one-third and half of the men who have diabetes will experience erectile dysfunction at some point ${ }^{(4)}$. The prevalence of diabetes throughout the world has increased dramatically over the recent past, and the trend will continue for the foreseeable future. One of the major concerns associated with diabetes relates to the development of micro-and macro-vascular complications, which contribute greatly to the morbidity and maturity associated with the disease ${ }^{(6)}$.

The World Health Organization has projected that 221 million and 300 million people will be affected by the disease between 2015 and $2025^{(7)}$. While diabetes is the most common among the elderly in many populations, prevalence rates are significantly rising among comparatively young and productive populations in the developing world ${ }^{(8)}$. As of 2012, an estimated 346 million people have type 2 diabetes ${ }^{(9)}$.

With the numbers of people affected by diabetes multiplying worldwide, the disease is taking an ever increasing proportion of national and international health care strategies ${ }^{(10)}$. It is projected to be one of world's main killers within the next 25 years. The most affected areas are Asia and Africa, where diabetes rates are expected to rise by two-three folds by $2030^{(11)}$.

Though, conventional synthetic drugs have made considerable progress in the management of diabetes, traditional plant treatments for diabetes are also being used throughout the world and the search for natural antidiabetes plant produces for controlling diabetes is on-going. Various ethno-pharmacological surveys have shown that a number of medicinal plants have been used for the treatment of diabetes with various authors attesting to the efficacy of the plants in the control of both types I and II diabetes ${ }^{(12)}$. Despite the introduction of hypoglycemic agents from natural and synthetic sources, diabetes and its related complications continue to be a major medical problem ${ }^{(13)}$. Currently available oral hypoglycemic agents for clinical use have characteristic profile of side effects and due to ever unceasing price of drugs especially in developing countries, a need to search for cheap drugs from natural source becomes imperative. In accordance with the recommendations of the World Health Organization, anti-hyperglycemic agent of plant origin used in traditional medicines seems important ${ }^{(14)}$.

Plants have always been a source of drugs for humans since time immemorial. It has been used as sources of drugs for the treatment of diabetes in the developing countries where the cost conventional medicines are burden to the population. According to World Health Organization, up to $90 \%$ of populations in developing countries use plants and its products as medicines for primary health care. Among the Yorubas (South-West Nigeria), hot water infusion of the plant of Ipomoea batatas continues to be highly valued in the local management of diabetes because of its effectiveness in the control of blood glucose and its low cost. Therefore, the present study investigates the blood glucose lowering effect of aqueous extract of Ipomoea batatas in alloxan-induced diabetic rats as a way of managing diabetes mellitus and also to identify the phytochemicals present in the extract.

\subsection{Collection of laboratory Animals (rats) and plant materials (Ipomoea batatas)}

Young male 6-8 weeks old Wister rats and weighing between 75 - 150g were purchased from FAS Venture Animal house, Elite road, Abeokuta, Ogun State. The animals were collected in a metal cage and transported to the animal house of Moshood Abiola Polytechnic, Abeokuta. The animals (rats) were acclimatized for 21 days before being subjected to experimentalstudy. The rats were kept in plastic perforated cages and maintained under standard conditions. They were then allowed free access to rat pellets obtained at Animals Arena Isabo, Abeokuta, Ogun State and portable water throughout the period of experimentation while fresh whole plants of Ipomoea batatas was collected from a farm at Osiele, Abeokuta, Ogun State, Nigeria.

\subsection{Preparation of the plant extract}

$200 \mathrm{~g}$ of air dried leaves of Ipomoea batatas was boiled with 1.5 litres of water for 40 minutes, after which it was rapidly filtered through a muslin cloth. The filtrate was them allowed to evaporate for another 45 minutes to give a brownish - black almost solid residue ${ }^{(15)}$. 


\subsection{Preparation of the rats for induction}

Four rats were housed in each cage. Four cages were used for the experiment, one cage for the nondiabetic group while the other three group were for the alloxan induced group. All cages were numbered for proper identification, while all animals were marked with water resistant makers on their body. After three weeks of acclimatization to the facility, induction began.

\subsection{Induction of diabetes}

Diabetes was induced by intraperitional administration of $150 \mathrm{mg} / \mathrm{kg}$ body weight of freshly prepared alloxan (Qualikems fine Chemical Private Limited, 5531, Basti Thana road, Delhi, India). In this method, the rats were restrained to keep calm. The rats were turned over so that the abdomen was exposed, a forceps was used to lift up the vein, after which the area was swabbed with $70 \%$ ethanol and induction was done with a $2 \mathrm{ml}$ syringe and needle, after which fasting blood glucose levels were obtained ${ }^{(16)}$.

Six hours after alloxan injection, rats were orally infused with 5\% analytical glucose at an oral dose of $5 \mathrm{ml}$ each so as to prevent the onset of fatal hypoglycemia, which often accompanies administration of alloxan as a result of acute massive pancreatic release of insulin. Twenty four hours later, the fasting blood glucose values of the alloxan - induced rats were determined using the glucometer. Rats with the fasting blood glucose levels above $200 \mathrm{mg} / \mathrm{dl}$ were selected and distributed into three groups of four rats in each group addition to a group containing normoglycemic rats which served as an untreated control group. Groups A, B, and C which are the allox.an-induced hyperglycemic rats were orally treated with the single daily oral doses of $400 \mathrm{mg} / \mathrm{kg}, 200$ $\mathrm{mg} / \mathrm{kg}$ and $300 \mathrm{mg} / \mathrm{kg}$ of Ipomoea batatas respectively. All the rats were treated for 14 days.

\subsection{Collection of blood sample for final blood glucose level analysis}

The rats' blood samples were collected after acclimatization, 24 hours after induction with alloxan and after 14 days treatment with aqueous extract of Ipomoea batatas for the determination of the blood glucose level of the rats. The blood samples were collected from the tail using a lancet after which fasting blood glucose level was determined ${ }^{(15)}$.

\subsection{Determination of fasting blood glucose}

After an overnight fast, blood samples for fasting blood glucose determination were obtained from the experimental rats by gently nipping the rat tail with lancet. The tails were gently squeezed to let out two or three drops of fresh venous whole blood which were placed in the sample well of the glucose strip which was then inserted into the glucometer. The blood glucose monitor was calibrated and validated at the beginning of midway and into the end of the experiment fasting blood glucose was determined using one touch fine test basic glucose monitoring meter ${ }^{(15)}$.

\subsection{Phytochemical screening of Ipomoea batatas}

The leaves of Ipomoea batatas were air dried for four weeks and then ground into fine powdered form for qualitative and quantitative analysis. The powdered plant material was extracted in $200 \mathrm{ml}$ of distilled water on a mechanical shaker for 48 hours. The extract was filtered using a Buchner funnel and Whatman No. 1 Filter paper and sterile cotton wool. The filtrate of the extract was frozen at $-40^{\circ} \mathrm{C}$ and dried for 48 hours.

\subsubsection{Qualitative test}

Qualitative analyses and Chemical tests were carried out on the extract using standard procedure to identify the constituents.

\subsubsection{Test for tannins}

$1 \mathrm{ml}$ of the plant extract was boiled in $20 \mathrm{ml}$ of distilled water in a test tube and then filtered. A few drops of $0.1 \%$ ferric chloride was added to the filtrate. A blue-black coloration was observed, which confirms the presence of tannin ${ }^{(17)}$.

\subsubsection{Test for phlobatannis}

$2 \mathrm{ml}$ of the plant extract was boiled with $1 \%$ aqueous hydrochloric acid. A red precipitate was deposited which was taken as evidence for the presence of phlobatannins ${ }^{(18)}$.

\subsubsection{Test for saponins}

$5 \mathrm{ml}$ of the plant extract was boiled in $20 \mathrm{ml}$ of distilled water in a water bath and filtered. Then $10 \mathrm{ml}$ of the filtrate was mixed with $5 \mathrm{ml}$ of distilled water and shaken vigorously for a stable persistent froth. The frothing was mined with 3 drops of olive oil and shaken rigorously, the formation of emulsion was observed which confirms a positive test of $\operatorname{saponin}^{(17)}$. 


\subsubsection{Test for flavonoids}

$3 \mathrm{ml}$ of $1 \%$ aluminium chloride solution was added to $5 \mathrm{ml}$ of the plant extract. A yellow coloration was observed indicating the presence of flavonoids. $5 \mathrm{ml}$ of dilute ammonia solution was added to the above mixture followed by the addition of concentrated $\mathrm{H}_{2} \mathrm{SO}_{4}$, which gave a yellow coloration that disappeared on standing. The yellow coloration which disappeared on standing indicates the presence of flavonoids ${ }^{(19)}$.

\subsubsection{Test for steroids}

$2 \mathrm{ml}$ of acetic anhydride was added to $2 \mathrm{ml}$ of the plant extract of each sample followed by careful addition of $2 \mathrm{ml} \mathrm{H}_{2} \mathrm{SO}_{4}$. The color changed from violet to blue which indicates the presence of steroids ${ }^{(20)}$.

\subsubsection{Test for alkaloids}

$1 \mathrm{ml}$ of the plant extract was stirred with $5 \mathrm{ml}$ of $1 \%$ aqueous $\mathrm{HCl}$ on a steam bath and filtered while hot. Distilled water was added to the residue and $1 \mathrm{ml}$ of the filtrate was treated with a few drops of Mayer's reagent (Potassium mercuric iodide solution). A cream colour was formed with Mayer's reagent which gives a positive test for alkaloids ${ }^{(18)}$.

\subsubsection{Test for anthraquinones}

$5 \mathrm{ml}$ of the plant extract was mixed with $10 \mathrm{ml}$ Benzene. The solution was then filtered and $5 \mathrm{ml}$ of $10 \%$ ammonia solution added to the filtrate. The mixture was shaken and the presence of pink colour in the ammonia (lower) phase indicated the presence of anthraquinones ${ }^{(18)}$.

\subsubsection{Test for Phenols}

$5 \mathrm{ml}$ of the plant extract was pipetted into a $30 \mathrm{ml}$ test tube. Then $10 \mathrm{ml}$ of distilled water was added. $2 \mathrm{ml}$ of ammonium hydroxide solution and $5 \mathrm{ml}$ of concentrated amyl alcohol were also added and left to react for 30 minutes. The development of a bluish green colour was taken as evidence for the positive test for phenol ${ }^{(17)}$.

\subsubsection{Test for terpenoids (Salkowski test)}

$5 \mathrm{ml}$ of the plant extract was mixed with $2 \mathrm{ml}$ of chloroform and $3 \mathrm{ml}$ of concentrated sulphuric acid was carefully added to form a layer. The interface formed a reddish brown colour which confirms the presence of terpenoids ${ }^{(20)}$.

\subsubsection{Test for glycoside as cardenolides (Keller-killani test)}

$5 \mathrm{ml}$ of the plant extract was treated with $2 \mathrm{ml}$ of glacial acetic acid containing one drop of ferric chloride solution. This was underplayed with $1 \mathrm{ml}$ of concentrated sulphuric acid. A brown ring at the interface indicates deoxy sugar characteristics of cardenolides which confirms a positive test forcardenolides. A violetgreen ring appearing below the brown-ring in the acetic acid layer indicates the positive test for glycoside ${ }^{(20)}$.

\subsubsection{Quantitative test}

\subsubsection{Determination of alkaloids}

$2 \mathrm{~g}$ of finely ground sample of the Ipomoea batatas plant was weighed and $100 \mathrm{ml}$ beaker and $20 \mathrm{ml}$ of $80 \%$ absolute alcohol added to give a smooth paste. The mixture was transferred to a $250 \mathrm{ml}$ flask and more alcohol added to make up to $100 \mathrm{ml}$ and $1 \mathrm{~g}$ magnesium oxide was then added. The mixture was digested in a boiling water bath for $15 \mathrm{hrs}$ under reflux air condenser with occasional shaking. The mixture was filtered while hot through a small buchner funnel. The residue was returned to the flask and re-digested for $30 \mathrm{mins}$ with $50 \mathrm{ml}$ alcohol after which the alcohol was evaporated. Hot water was added to replace the alcohol lost. When all the alcohol had been removed, 3 drops of $10 \% \mathrm{HC} 1$ were added. The whole solution was later transferred into a $250 \mathrm{ml}$ volumetric flask, $5 \mathrm{ml}$ of zinc acetate solution and $5 \mathrm{ml}$ of potassium ferrocyanide solution were added, and the solution was thoroughly mixed to give a homogenous solution. The flask was allowed to stand for a few minute and filtered through a dry filter paper and $10 \mathrm{ml}$ of the filterate was transferred into a separating funnel and the alkaloids present were extracted vigorously by shaking with five successive portions of chloroform. The residue obtained was dissolved in $10 \mathrm{ml}$ hot distilled water and transferred into a Kjeldahl tube with the addition of $0.02 \mathrm{~g}$ sucrose and $10 \mathrm{ml}$ of concentrated $\mathrm{H}_{2} \mathrm{SO}_{4}$ and $0.02 \mathrm{~g}$ selenium was added and digested to a colorless solution to determine the percentage of nitrogen $(\% \mathrm{~N})$ by Kjeldahl distillation method ${ }^{(21,22)}$.

$\%$ alkaloids $=\% \mathrm{~N} \times 3.26$

\subsubsection{Determinationof flavonoids}

$0.50 \mathrm{~g}$ of finely ground sample of Ipomoeabatataswas weighed into $100 \mathrm{ml}$ beaker and $80 \mathrm{rn} 1$ of $95 \%$ ethanol was added and stirred with a glass rod to prevent lumping. The mixture was filtered through a Whatman 
No. 1. Filter paper into a $100 \mathrm{ml}$ volumetric flask and made up to the mark with ethanol. $11 \mathrm{ml}$ of the extract was pipetted into $50 \mathrm{~m} 1$ volumetric flask. Four drops of Concentrated $\mathrm{HCl}$ were then added with a dropping pipette after which $0.5 \mathrm{~g}$ of magnesium turnings were added to develop a magenta red coloration. Standard flavonoid solutions of range $0-5 \mathrm{ppm}$ was prepared from 100ppm stock solution and treated in a similar way with $\mathrm{HCl}$ and magnesium turnings. The absorbance of magenta red coloration of sample and standard solutions were read on a digital Jenway V6300 spectrophotometer at a wavelength of 520nm. ${ }^{(23)}$. The percentage flavonoid was calculated using the formula:

$\%$ flavonoid $=\underline{\text { Absorbance of sample } \mathrm{X} \text { average gradient factor } \mathrm{x} \text { dilution factor }}$ Weight of Sample x 10,000

\subsubsection{Determination of tannins}

$0.20 \mathrm{~g}$ of the plant (sample) extract was added into a $50 \mathrm{~m} 1$ beaker. $20 \mathrm{~m} 1$ of $50 \%$ methanol was then added. The beaker was then covered with paraffin and placed in water bath at $77-80^{\circ} \mathrm{C}$ for 1 hour. The mixture was shaken thoroughly to ensure uniform mixing. The extract was quantitatively filtered (using a double layered whatman No 4 Filter paper) into a $100 \mathrm{ml}$ volumetric flask. $20 \mathrm{~m} 1$ water, $2.5 \mathrm{~m} 1$ folin- Denis reagent and $10 \mathrm{ml}$ of $17 \% \mathrm{Na}_{2} \mathrm{CO} 3$ were added and mixed properly. The mixture was made up to mark with water, mixed well and allowed to stand for 20mins. The bluish - green colour which developed at the end of range of $0-10 \mathrm{ppm}$, were treated similarly as $1 \mathrm{ml}$ standard samples. The absorbance of the tannic acid standard solution as well as sample was read after color development on a spectronic 21D spectrophotometer at a wave length of $760 \mathrm{~nm}^{(24)}$.Percentage of tannin was calculated using the formula:

$\%$ Tannin $=\underline{\text { Absorbance of the sample } \mathrm{x} \text { dilution factor gradient }}$

Weight of the sample $\mathrm{x} 10,000$

\subsubsection{Determination of saponins}

$1 \mathrm{~g}$ of finely ground sample of Ipomoea batataswas weighed into a $250 \mathrm{ml}$ beaker and $100 \mathrm{ml}$ of isobutyl alcohol was added. The mixture was shaken on a UDY shaker for 5 hours to ensure uniform mixing. Thereafter, the mixture was filtered (through a Whatman No 1 Filter paper) into $100 \mathrm{ml}$ beaker and $20 \mathrm{ml}$ of $40 \%$ saturated solution of magnesium carbonate was added. The mixture obtained with saturated magnesium carbonate was again filtered through a Whatman No. 1 Filter paper to obtained a clear colourless solution. $1 \mathrm{ml}$ of the colourless solution was pipetted into $50 \mathrm{ml}$ volumetric flask and $2 \mathrm{ml}$ of $5 \%$ of ferric chloride solution was added and made up to the mark with distilled water. The solution was allowed to stand for 30 mins for blood red colouration to develop. 0 - 10ppm standard saponin solutions were prepared from saponin stock solution. The standard solution was treated similarly with $2 \mathrm{ml}$ of $5 \%$ ferric chloride solution as done for $1 \mathrm{ml}$ sample above. The absorbance of the sample as well as standard saponin solutions were read (after color development) in a Jenway V6300 spectrophotometer at a wavelength of $380 \mathrm{~mm} .{ }^{(25)}$.

$\%$ Saponin $=\frac{\text { Absorbance of sample } \times \text { Gradient factor } \times \text { Dilution factor }}{\text { A }}$

Weight of sample $\mathrm{x} 10,000$

\subsubsection{Determination of glycosides}

$10 \mathrm{ml}$ of the plant extract was pipette into a $250 \mathrm{ml}$ conical flask. $50 \mathrm{ml}$ chloroform was added and shaken on a mixer for $1 \mathrm{hr}$. The mixture was filtered into $100 \mathrm{ml}$ conical flask containing $10 \mathrm{ml}$ of pyridine. $2 \mathrm{ml}$ of $2 \%$ sodium nitroprusside was added, shaken thoroughly for $10 \mathrm{mins} .3 \mathrm{ml}$ of $20 \%$ sodium hydroxide was later added to develop a brownish yellow colour. Glycoside standards of concentration which ranges from 0 $5 \mathrm{mg} / \mathrm{ml}$ were prepared from $100 \mathrm{mg} / \mathrm{ml}$ stock glycoside standard. The series of standards $0-5 \mathrm{mg} / \mathrm{ml}$ were treated similarly like the sample above. The absorbance of the sample as well as the standards was read on a spectronic 21D digital spectrophotometer at a wavelength of $510 \mathrm{~nm}{ }^{(25)}$. Percentage of glycoside was calculated using the formula:

$\%$ glycoside $=\underline{\text { Absorbance of sample } \mathrm{X} \text { Gradient factor } \mathrm{x} \text { Dilution factor }}$

Weight of Sample x 10,000

\subsection{Statistical analyses}

Test of significance was conducted by analysis of Variance (ANOVA) and separation of means by Duncan's multiple ranges Test (DMRT) at $5 \%$ probability level. 
3.1 Results

\section{Results And Discussion}

\subsubsection{Effects of different quantities $(200 \mathrm{mg} / \mathrm{kg} / \mathrm{day}, 300 \mathrm{mg} / \mathrm{kg} / \mathrm{day}$ and $400 \mathrm{mg} / \mathrm{kg} / \mathrm{day})$ of} Ipomoea batatas leaf aqueous extracts on sugar level of alloxan- induced diabetic rats.

Table 1 showed the hypoglycemic effects of different quantities $(200 \mathrm{mg} / \mathrm{kg} / \mathrm{day}, 300 \mathrm{mg} / \mathrm{kg} / \mathrm{day}$ and 400 $\mathrm{mg} / \mathrm{kg} /$ day) of Ipomoea batatas leaf extract. The results showed that there was no significant difference $(\mathrm{p}>0.05)$ in the fasting glucose level of all the experimental rats before induction. The sugar level of rats increased after alloxan induction of the rats compared with non-diabetic group (normoglycaemic rats). It was observed also that oral treatment with $200 \mathrm{mg} / \mathrm{kg} /$ day of Ipomoea batatas aqueous extracts did not produce much significant ( $p>0.05)$ alterations in the blood glucose concentration level when compared with basal value because high level of sugar was still observed in alloxan - induced rats treated with of $200 \mathrm{mg} / \mathrm{kg} / \mathrm{day}$ of leaf extract $(245.60 \pm 7.72 \mathrm{mg} / \mathrm{dl})$ of Ipomoea batatas even till the last day of the experiment, indicating diabetic condition of the rats (hyperglycemia). Also, there was no significant difference $(\mathrm{p}>0.05)$ in the sugar level of rats treated with of $300 \mathrm{mg} / \mathrm{kg} / \mathrm{day}$ and $400 \mathrm{mg} / \mathrm{kg} /$ day of the extracts but this hypoglycemic effect significantly different $(\mathrm{p}<0.05)$ from non-diabetic and rats treated with oral administration of $200 \mathrm{mg} / \mathrm{kg} /$ day Ipomoea batatas extracts.

At the end of 14 days, percentage maximum dose-dependent reductions of blood glucose concentrations of 52.18 percentwas recorded in rats treated with $200 \mathrm{mg} / \mathrm{kg} / \mathrm{day}, 69.67$ percent was recorded in $300 \mathrm{mg} / \mathrm{kg} /$ day extract while 59.24 percent was recorded in sugar level of alloxan-induced rats treated with 400 $\mathrm{mg} / \mathrm{kg} /$ day of Ipomoea batatasleaf extracts and these values are statistically $(\mathrm{p}<0.05)$ different from those of the control. The non-diabetic induced rats (normoglycaemic rats) exhibited steady increase $(8.03 \%)$ in their normal glucose level throughout the experimental period.

Table 1: Mean sugar level (mg/dl) of rats treated with Ipomoea batatasleaf aqueous extract

\begin{tabular}{|c|c|c|c|c|c|}
\hline \multirow[t]{2}{*}{ Treatment groups } & \multirow[t]{2}{*}{ Dosage $(\mathrm{m})$} & \multicolumn{4}{|c|}{ Glucose levels $(\mathrm{mg} / \mathrm{dl})$ post treatment with the extracts } \\
\hline & & Before induction & After induction & After treatment $\%$ & \\
\hline Ipomoea batatasleaf extract. & $200 \mathrm{mg} / \mathrm{kg} /$ day & $108.40 \pm 12.65^{\mathrm{a}}$ & $513.60 \pm 28.45^{\mathrm{b}}$ & $245.60 \pm 7.72^{c}$ & 52.18 \\
\hline Ipomoea batatasleaf extract. & $300 \mathrm{mg} / \mathrm{kg} /$ day & $103.80 \pm 2.42^{\mathrm{a}}$ & $463.60 \pm 11.73^{\mathrm{b}}$ & $140.60 \pm 8.59 \mathrm{a}^{\mathrm{b}}$ & 69.67 \\
\hline Ipomoea batatasleaf extract. & $400 \mathrm{mg} / \mathrm{kg} /$ day & $92.40 \pm 9.84^{\mathrm{a}}$ & $425.40 \pm 53.33^{b}$ & $173.40 \pm 40.38^{\mathrm{b}}$ & 59.24 \\
\hline Non diabetic (Normal) & Distilled water & $100.80 \pm 3.81^{\mathrm{a}}$ & $104.60 \pm 4.31^{\mathrm{a}}$ & $96.20 \pm 2.44^{\mathrm{a}}$ & 8.03 \\
\hline
\end{tabular}

Mean followed by the same letters on the same columns are not significantly different according to Duncan's Multiple Range Test at 5\% probability.

\subsubsection{Effect of different quantities of Ipomoea batatasleaf aqueous extracts on body weights of alloxan -} induced diabetic rats

Table 2 showed the effects of $2 \mathrm{ml} / \mathrm{kg}$ oral administration of different quantities $(200 \mathrm{mg} / \mathrm{kg} / \mathrm{day}$, $300 \mathrm{mg} / \mathrm{kg} / \mathrm{day}$ and $400 \mathrm{mg} / \mathrm{kg} /$ day) of Ipomoea batatas aqueous extracts for 14 days on the body weights of alloxan - induced diabetic rats. The results revealed significant different $(\mathrm{p}<0.05)$ in the weights of the rats before the rats were induced. After alloxan induction, no significant difference $(p>0.05)$ was observed in their weights. At the end of oral treatment, it was observed that there was no significant difference $(p>0.05)$ in the weights of the experimental rats treated with $200 \mathrm{mg} / \mathrm{kg} /$ day and $300 \mathrm{mg} / \mathrm{kg} /$ day of the extracts, an effect which was different significantly $(\mathrm{p}<0.05)$ from the weights of rats treated with $400 \mathrm{mg} / \mathrm{kg} / \mathrm{day}$ and non-diabetic rats.

It was revealed that at the end of 14 days of oral treatment, alloxan - induced rats treated with 200 $\mathrm{mg} / \mathrm{kg} /$ day, $300 \mathrm{mg} / \mathrm{kg} / \mathrm{day}$ and $400 \mathrm{mg} / \mathrm{kg} /$ day sustained percentage of $48.91,28.66$ and 31.11 percents respectively compared with non diabetic - induced rats which recorded percent loss of $0 \%$ which means they maintained their weights. Similar effect was observed except in alloxan-induced rats treated with $400 \mathrm{~m} / \mathrm{kg} / \mathrm{day}$ of the extract of Ipomoea batatas, and non-diabetic rats.

Table 2: Mean weights of rats treated with Ipomoea batatasleaf aqueous extract

\begin{tabular}{|c|c|c|c|c|c|}
\hline \multirow{2}{*}{ Treatment groups } & \multirow{3}{*}{ Dosage } & \multicolumn{4}{|c|}{ Weights $(\mathrm{g})$ post treated with the extracts } \\
\hline & & \multicolumn{4}{|c|}{ Before induction After induction After treatment $\%$ Weight reduction } \\
\hline $\begin{array}{l}\text { Ipomoea batatasleaf } \\
\text { extract. }\end{array}$ & & $95.30 \pm 4.95^{\mathrm{b}}$ & $97.06 \pm 5.22^{b}$ & $49.58 \pm 0.65^{\mathrm{b}}$ & 48.92 \\
\hline $\begin{array}{l}\text { Ipomoea batatasleaf } \\
\text { extract. }\end{array}$ & $300 \mathrm{mg} / \mathrm{kg} / \mathrm{day}$ & $90.28 \pm 6.12^{\mathrm{ab}}$ & $90.28 \pm 6.12^{\mathrm{ab}}$ & $67.30 \pm 6.61^{b}$ & 28.66 \\
\hline $\begin{array}{l}\text { Ipomoea batatasleaf } \\
\text { extract. }\end{array}$ & $400 \mathrm{mg} / \mathrm{kg} /$ day & $75.11 \pm 0.01^{\mathrm{a}}$ & $76.56 \pm 0.50^{\mathrm{a}}$ & $52.74 \pm 2.00^{\mathrm{a}}$ & 31.11 \\
\hline
\end{tabular}



Non
diabetic Distilled water
$90.16 \pm 1.11^{\mathrm{ab}}$
$90.16 \pm 6.11^{\mathrm{ab}}$
$90.16 \pm 6.11^{\mathrm{c}}$
0.00

Mean followed by the same letters on the same columns are not significantly different according to Duncan's Multiple Range Test at 5\% probability.

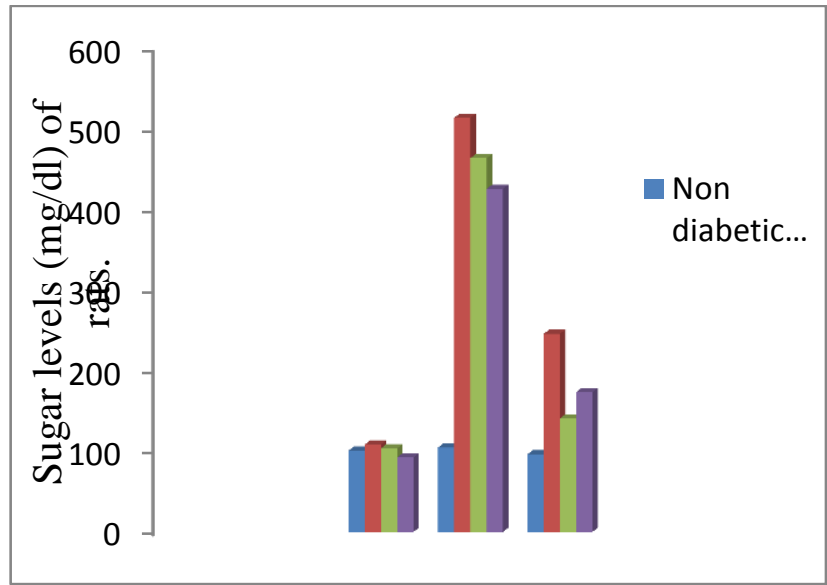

$200 \mathrm{mg} / \mathrm{kgI}$. batatas

$300 \mathrm{mg} / \mathrm{kgI}$. batatas

$400 \mathrm{mg} / \mathrm{kgI}$. batatas

Fig 2:Hypoglycaemic effect of different dosage of aqueous extract of Ipomoeabatatasleaf on rats.

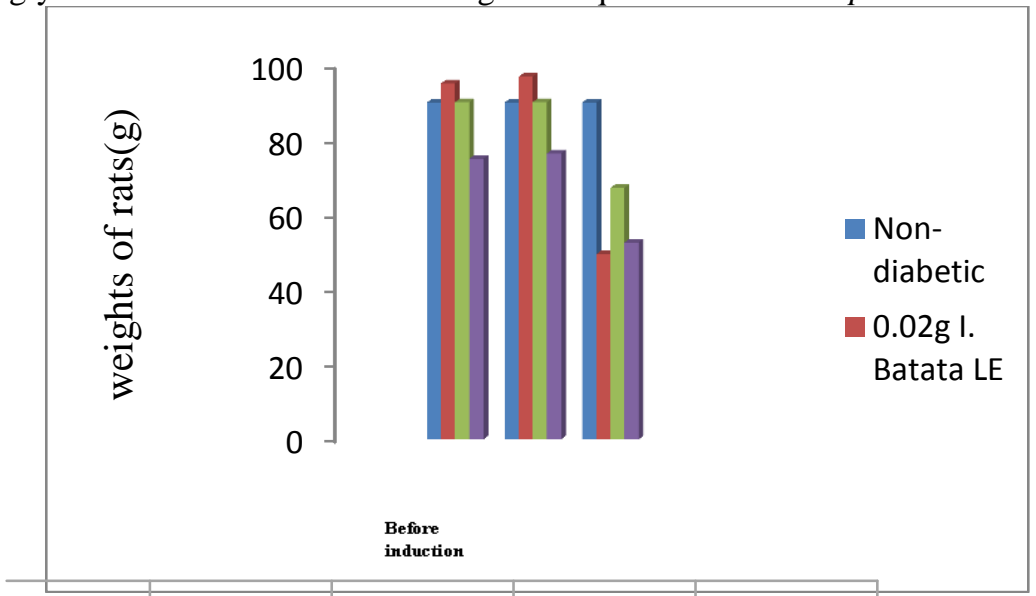

$200 \mathrm{mg} / \mathrm{kg}$ I. batatas

$300 \mathrm{mg} / \mathrm{kg}$ I. batatas

$400 \mathrm{mg} / \mathrm{kg}$ I.batatas

Fig3: Effect of different dosage of aqueous extract of Ipomoea batatasleaf on weights of rats.

\subsubsection{Results of qualitative and quantitative screening of Ipomoea batatas aqueous extract}

The qualitative Phytochemical screening analyses of Ipomoea batatas revealed the presence of alkaloids, flavonoids, tannins, saponins, steroids, phenol, anthraquinone, phlobotannin, glycoside and terpenoid in the extract while the quantitative screening showed that saponins, tannins, anthraquinones and flavonoids contains the $6.21 \%, 4.15 \%, 3.11 \%$ and $21.6 \%$ respectively. The phytochemical with the highest quantity is saponin while the one with the lowest quantity is glycosides (Table 3).

Table 3: Qualitative and quantitative phytochemical screening of I. batatasleaf

\begin{tabular}{|c|c|c|}
\hline Phytochemicals & Qualitative & Quantitative (\%) \\
\hline Tannins & ++ & 4.15 \\
\hline Saponin & ++ & 6.21 \\
\hline Flavonoid & ++ & 2.16 \\
\hline Alkaloids & + & 1.81 \\
\hline Steroids & + & 0.92 \\
\hline Phenol & + & 0.81 \\
\hline Anthraquinone & ++ & 3.11 \\
\hline Phlobatannin & + & 0.48 \\
\hline Glycosides & + & 0.40 \\
\hline Terpenoides & + & 0.76 \\
\hline
\end{tabular}

\begin{tabular}{lll}
\hline Key: & & \\
+ & $=$ & Low \\
++ & $=$ & Moderate
\end{tabular}


$+++\quad$ High

\subsection{Discussion}

The qualitative phytochemical screening analyses of Ipomoea batatas revealed presence of alkaloids, flavonoids, tannins, saponins, steroids, phenol, anthraquinine, phlobatannin, glycosides and terpenoids. Also, quantitative analysis of Ipomoea batatas secondary metabolites revealed that the plant contained moderate amount of alkaloids $(1.81 \%)$, flavonoids $(2.16 \%)$, tannins $(4.15 \%)$, saponins $(6.21 \%)$, steroids $(0.92 \%)$, phenol $(0.81 \%)$, anthraquinone $(3.11 \%)$, phlobatannin $(0.48 \%)$, glycosides $(0.40 \%)$ and terpenoids $(0.76 \%)$. The antihyperglycaemic effect of the plant may be due to a number of factors; Ipomoea batatas leaf extract is rich in secondary metabolites that have been reported to possess anti-hyperglycemic activities such as alkaloids and saponins known to be bioactive against diabetes ${ }^{(26)}$. Terpenoids, flavonoids, glycosides and alkaloids have also been recorded to be frequently implicated with hypoglycaemic activities ${ }^{(27)}$. However, the oral hypoglycemic effect of Ipomoea batatas could be due to the presence of one or more phytocomponents contained in the extract.It has been shown that the biological activities of alkaloids and flavonoids include hypoglycemic, hypolipidemia, hypotension among other biological activities. Flavonoids have also been documented to possess immunomodulating activity and antioxidant properties in addition to its hypoglycemic, hypolipidemic, and antiatherosclerotic effects. The presence of these active phytocomponents in Ipomoea batatasleaf extractmay be responsible for the observed hypoglycemic effect, although further studies are required to confirm this suggestion. In addition, the efficacy of the extract on hyperglycemic rats corroborates the results of Adikwuet al. (28) who had systematically demonstrated that the extract from the plant possesses anti-diabetic properties. The activity of the extract is attributable to the phytoconstituents of the plant part.

The variation observed in the hypoglyceamic effect of Ipomoea batatas could be due to differences in the quantities of the extract. Thus, this finding is in accord with that reported for Ipomoea batatas hot infusion of the whole parts in alloxan-induced diabetic rats by Aderonkeet al. ${ }^{(29)}$.

Also, literature has equally shown the biological activities of alkaloids and flavonoids to include hypoglycemia, hypolipidemia, hypoazotemia, hypotension among other biological effects ${ }^{(30,31)}$. The presence of these two active biological principles in high concentrations in Ipomoea batatasleaf extracts may be responsible for the oral hypoglycemic effects recorded in the present study. These hypoglycemic effects could also have been mediated either via induction of hyperinsulinemia (increased pancreatic insulin secretion) or increased peripheral utilization of glucose. The latter appears more plausible as the beta pancreatic cells were already destroyed by the alloxan injection.

The effects of different dosage of Ipomoea batatas leaf aqueous extracts on sugar level of alloxaninduced diabetic rats showed that there was no significant difference $(p>0.05)$ in the fasting glucose level of all the experimental rats before the trial was initiated. This implied that all the experimental rats before the trial had similar level of sugar concentration $(100.81,103.8,108.40,92.40,100.80,104.60$, and 100.80). The sugar level of the rats increased significantly after alloxan induction compare with non-diabetic group. Oral treatment with $200 \mathrm{mg} / \mathrm{kg} /$ day of Ipomoea batatas aqueous extracts did not produce much significant ( $>0.05)$ alterations in the blood glucose concentration level after treatment compared with basal value because high sugar level was observed in alloxan - induced rats. This is an indication that the dosage was small and may not be potent enough on the sugar level of rats because the rats were still in their diabetic conditions (hyperglycemia) even at the end of the experiment.

$300 \mathrm{mg} / \mathrm{kg} /$ day of the extract significantly $(\mathrm{p}<0.05)$ enhanced glucose reduction relatively to baseline glycaemia after 14 days, an effect which was similar to that produced by $400 \mathrm{mg} / \mathrm{kg} / \mathrm{day}$. This observation is in line with the findings of Jain and Longerhan ${ }^{(32)}$ which reported a hypoglycemic effect in alloxan-induced diabetic rats at 200 and $400 \mathrm{mg} / \mathrm{kg}$ with the use of Spinaciaoleraceae. Also, Odutugaet al., ${ }^{(33)}$, in his investigation on anti-diabetic effect of Morindalucidastem bark extract on alloxan - induced diabetic rats reported maximum percentage reduction of 73.5 and $93.0 \%$ in blood glucose concentration of metanolic leave extract of Morindalucida at $240 \mathrm{mg} / \mathrm{kg}$ body weight.

At the end of the 14 - day studies, the aqueous extracts of Ipomoea batatas exhibited maximum percentage dose dependent effect. Thehighest percentage blood sugar reductions of $69.67 \%$ was recorded in rats treated with $300 \mathrm{mg} / \mathrm{kg} /$ day, followed by $59.24 \%$ for $400 \mathrm{mg} / \mathrm{kg} /$ day treatment while the least percentage sugar reduction of $52.18 \%$ was observed in $200 \mathrm{mg} / \mathrm{kg} /$ day extract. This suggests that the treatment with 300 $\mathrm{mg} / \mathrm{kg} /$ day of Ipomoea batatas leaf extract was more active than $200 \mathrm{mg} / \mathrm{kg} /$ day and $400 \mathrm{mg} / \mathrm{kg} / \mathrm{day}$ doses in this study. These results are in line with the observation of Osinubiet al. ${ }^{(34)}$ who recoded maximum percentage reduction of $11.46,13.42$ and $17.75 \%$ in blood glucose concentrations of leaf extract of Tapinanthusbutungii at 200,300 and $400 \mathrm{mg} / \mathrm{kg}$ body weight respectively.

Soon and Tan, ${ }^{(35)}$, observed that oral administration of the fraction $(50 \mathrm{mg} / \mathrm{kg})$ produced a significant elevation of $23 \%, 36 \%$ and $31 \%$ from the 0 hour fasting serum glucose levels of the diabetic rats at the first, second and third hours respectively. 
However, with maximum decreases of 52.18, 69.67 and $59.24 \%$ respectively $200 \mathrm{mg} / \mathrm{kg}, 300 \mathrm{mg} / \mathrm{kg}$ and $400 \mathrm{mg} / \mathrm{kg}$ considerably less than normal glycaemic index implied that the stimulation of the undamaged/survivor beta cells to facilitate insulin secretion appeared the likely mode. Similar explanation has been put forward on a number of plants believed to have anti-hyperglycaemic and insulin stimulatory effects ${ }^{(36,}$ 37, 38). It was obvious that the extracts effectively attenuated the diabetogenic agent inflammatory response to enhance the activity of insulin producing beta cells besides,saponins and glycosides found in the extract are strongly linked with hypoglycaemic activity with the saponins component speculated to act as direct hypoglycaemic agent ${ }^{(26)}$.

The potentiation of insulin release from the beta cells may have equally accounted for the hypoglycaemic effect observed in oral doses of Ipomoea batatas leaf extracts in alloxan induced rats. This agreed with the reports of similar findings on some other plants ${ }^{(39)}$.

Effects of different dosage of I. batatas leaf aqueous extracts on body weights of alloxan- induced diabetic rats revealed significant different $(p<0.05)$ in the weights of the rats before the rats were induced. After alloxan, no significant difference $(p>0.05)$ was observed in their weights. At the end of oral treatment, it was observed that there was no significant difference $(p>0.050)$ in the weights of experimental rats treated with $200 \mathrm{mg}$ and $300 \mathrm{mg}$ extracts. This effect was different significantly $(\mathrm{p}<0.05)$ from the weights of rats treated with $400 \mathrm{mg}$ and non-diabetic rats.

At the end of 14days of oral treatment, alloxan induced rats treated with $200 \mathrm{mg} / \mathrm{kg} / \mathrm{day}, 300$ $\mathrm{mg} / \mathrm{kg} / \mathrm{day}$ and $400 \mathrm{mg} / \mathrm{kg} /$ day sustained percentage weight loss of $48.91,28.66$ and 31.11 percent respectively compared with non-diabetic induced rats which recorded percent loss of zero (0).

General decrease in the body weight of the rats, treated with $200 \mathrm{mg} / \mathrm{kg} / \mathrm{day}, 300 \mathrm{mg} / \mathrm{kg} / \mathrm{day}$ and 400 $\mathrm{mg} / \mathrm{kg} / \mathrm{day}$ of the extractscaused a significant dose-dependent reduction in the body weight and percentage change in body weight of the treated rats. The decrease in body weight of the alloxan diabetic group could be due to wasting associated with diabetic patients as a result of increased utilization of fats from the adipose tissue for generation of energy in the body. Alloxan has been reported to cause massive reduction in insulin release by the destruction of the $\beta$-cells of islets of Langerhans and inducing hyperglycaemia in animals. Similar observation was made by Sini ${ }^{(40)}$ in his work on the beneficial effect of extract of Hibiscus sabdariffacalyces in alloxan - diabetic rats: Hypoglycaemic andhypolipidaemic activities.

It is well documented in the literature that weight loss improves insulin action in patients with impaired glucose tolerance. Thus, it is possible for Ipomoea batatas to be mediating its hypoglycemic effect via enhanced insulin action. From the foregoing, the oral hypoglycemic effect of Ipomoea batatasleaf extractappears to be mediated via increased peripheral utilization of glucose since the extract exhibited same biological effects. This observation agreed with the findings of Aderonkeet at., ${ }^{(29)}$.

It has been shown that streptozotocin and alloxan induced diabetes mellitus by causing pancreatic $b$ selective cytotoxicity, via disruption of the cell membrane integrity. The pancreatic beta - cells are known to be involved in the synthesis, storage, and release of insulin, the peptide hormone regulating carbohydrate, protein, and lipid metabolism. It is equally possible for Ipomoea batatas to have regenerated remnants of the already alloxan - destroyed cells. This remains a conjecture until scientifically demonstrated. In the light of the present study, the extract clearly exhibited effective glycaemic control by reversing high glucose level to basal glycaemia level.

\section{Conclusion}

In conclusion, the results of this study clearly demonstrated that $300 \mathrm{mg} / \mathrm{kg} /$ day aqueous leaf extract of Ipomoea batatas produced a pronounced and remarkable blood-glucose lowering potential of 69.67 percent in alloxan-induced diabetic rats, therefore, represents an effective anti-hyperglycemic dosage for the treatment of diabetes and the plant remains potential source for discovery of new orally active agent(s) for future diabetes therapy. The aqueous leave extract of Ipomoea batatas can be recommended to be used as an antidiabetic agent for patients living with diabetes due to the fact that it is cheap and also a natural agent. It can also be recommended as a potential source of diabetic drug for pharmaceutical industries.

\section{References}

[1]. Shoback G. and Gardener D. 2011. Prevalence of diabetes. 15:499 - 501.

[2]. Mellisa C. and William D. 2010. Diabetes mellitus . 13 - 16.

[3]. Rother K. 2007. Diabetes treatment - bridging the divide. 356 (16):501

[4]. Riserus U. and Willet W. 2009. Dietary fats and prevention of type 1 diabetes. $10-15$.

[5]. Seidell J. 2008. Obesity, insulin resistance and diabetes. A world of epidemics. 5 - 8.

[6]. Cefalu T. 2006. Animal models of type 2 diabetes in young people: a serious disease requiring impaired understanding and care. 47:3.

[7]. Amos A., Macorty D. and Zimmet P. 2010. The rising global burden of diabetes and its complications. $14: 7-85$.

[8]. International Diabetes Federation. 2009. Diabetes Overview.7-14.

[9]. World Health Organisation. 2012. The prevalence of type 2 diabetes. $6-18$. 
[10]. World Health Organisation. 2008. A concern for diabetes mellitus. 7 - 16

[11]. King H., Aubert R. and Herman W. 2010. Global burden of diabetes. 21: $1414-1431$

[12]. Villasenor M. and Lamarid R. 2006. Comparative anti-hyperglycemic potentials of medicinal plants. 129 - 131.

[13]. Bhaskar A., Vidhya G. and Ramya M. 2008. Hypoglycemic effect of Mucinapruriens seed extract on normal and streptozotocininduced diabetic rats. 79:539-573.

[14]. Kamejwara- Rao B., Kesarulo M. and Giri, R. 2007. Herbal medicines in the treatment of diabetes mellitus. $79-83$.

[15]. Olowu A., Adeneye A. and Adeyemi O. 2011. Hypoglycemic effect of the aqueous leaf and stem extract of Ipomoea batatas in normal and streptozotocin-induced diabetic rats. 2:56-61.

[16]. Ahmed F., Syed K., Ghari S., Shaik. And Ibrahim K. 2010. Antidiabetic activity of Vincaroseaextract in alloxan induced diabetes.1 -6 .

[17]. Harborne J. 1973. Phytochemical methods: A guide to modern technology of plants Analysis. 279.

[18]. Wall M., Eddy C., Mclenna M. and Klump M. 1952. Detection and estimation of steroid and sapogenins in plant tissue. 24:1337 1342 .

[19]. Sofowora A. 1993. Medicinal plants and traditional medicine in Africa. 1993:256.

[20]. Trease G. and Evans W. 1989. A journal of pharmacognosy. 53.

[21]. Allens S. 1992. Allens commercial organic analysis. 6:167-171.

[22]. Henry T. 1993. The plant alkaloids. 6-466.

[23]. Allens S. 1979. Allens commercial organic analysis. 9:156 - 189

[24]. Swain T. 1979. Tannins and lignins. Herbivores: their interaction with plant metabolites. $16-22$

[25]. Brunner J. 1984. Direct Spectrophotometer determination of Saponin. 34:1314 - 1326

[26]. Abdel-Hassan I., Abdel-Barry J. and Mohammeda T. 2000. The hypoglycaemic and antihyperglycaemic effect of Citrulluscocoynthis fruit aqueous extract in normal and alloxan diabetic rabbits. 71:325.

[27]. Loew S. and Kaszkin Y. 2002. The evaluation of the anti-hyperglycemic effects of Ipomoea batatas. 18 - 30.

[28]. Adikwu M., David C., Okoye T., Uzor P., Ogochukwu V. and Amadi B. 2010.Antidiabetic effect of combined aqueous leaf extract of Vernoniaamygdalina and metformin in rats.1: 197-202.

[29]. Aderonke O., Adejuwon A. and Olufunmilayo O. 2011. Hypoglycaemic effect of Ipomoea batatas aqueous leaf and stem extract in normal and streptozotocin-induced hyperglycaemic rats. 2:56 - 61.

[30]. Oladele B., Ayo O. and Adaudi O.1995. Medicinal and physiological properties of flavonoids, coumarin derivatives and anthraquinones of plant origin. 11: $134-144$

[31]. Sudheesh S., Manilal V. and Vijayalakshmi R. 2005. Potential health promoting effects of flavonoids, a comparative study on hypolipidaemicand hypoglycaemic activities. 179 .

[32]. Jain K. and Longanathan P. 2010. Hypoglycemic effect of Spinaciaoleracea in alloxan induced rats. 5(2):87 - 91.

[33]. Odutuga A., Dairo O., Minari B. and Bamisaye A. 2010. Anti-diabetic effect of Morindalucida stem Bark Extract on alloxan induced diabetic rats. $4(3): 78-82$.

[34]. Osinubi A., Ajayi G. and Adesitun E. 2006. Evaluation of the anti-diabetic effect of aqueous leaf extract of Tapinanthusbutungiin male sprague-dawley rats. 16:41-47.

[35]. Soon Y. and Tan B. 2002. Evaluation of the hypoglycemic and anti - oxidant activities of Morindaofficinalis in streptozotocin induced diabetic rats. 43(2): $77-85$.

[36]. Latha M. and Paris L. 2004. Effect of an aqueous extract of Scopariadulcison blood glucose, plasma insulin and some poly pathway enzymes in experimental rat diabetes. 37:577 - 586

[37]. Latha M. and Paris L. 2003. Antihyperglycaemic effect of Cassia auriculatain experimental diabetes and its effects on key metabolic enzymes involved in carbohydrate metabolism. 30:38 - 43.

[38]. Venkateswaran S. and Pari L. 2002. Effect of Cocciniaindicaon blood glucose, insulin and hepatic key enzymes in experimental diabetes. 40:165 - 170

[39]. Ivorra M., Paya M. and Villar A. 1988. Hypoglycaemic and insulin release effects of tormentic acid: a new hypoglycaemic natural product. 4:282 - 286

[40]. Sini B. 2011. Effect of extract of Hibiscus sabdariffa in alloxan-diabetic rats. $6-36$. 